\title{
Correction to: The effect of Frankia and multiple ectomycorrhizal fungal species on Alnus growing in low fertility soil
}

\author{
Haoran Chen ${ }^{1} \cdot$ Sylvie Renault ${ }^{1} \cdot$ John Markham ${ }^{1}$
}

Published online: 25 April 2020

(C) Springer Nature B.V. 2020

\section{Correction to: Symbiosis}

\author{
https://doi.org/10.1007/s13199-020-00666-Z
}

This erratum is being published to correct a spelling mistake in the title.

Before correction: The effect of Frankia and multiple ectomycorrhizal fungil species on Alnus growing in low fertility soil

After correction: The effect of Frankia and multiple ectomycorrhizal fungal species on Alnus growing in low fertility soil

Publisher's note Springer Nature remains neutral with regard to jurisdictional claims in published maps and institutional affiliations.

The online version of the original article can be found at https://doi.org/ 10.1007/s13199-020-00666-Z

Haoran Chen

chenh318@myumanitoba.ca

1 Department of Biological Sciences, University of Manitoba,

Winnipeg, Manitoba, Canada 